\title{
Design and Implementation of Battery Management System for Electric Bicycle
}

\author{
Muhammad Ikram Mohd Rashid ${ }^{1, *}$, and James Ranggi Anak Johnny Osman ${ }^{2}$ \\ ${ }^{1}$ Sustainable Energy \& Power Electronics Research Group, Fakulti Kejuruteraan Elektrik \& \\ Elektronik, Universiti Malaysia Pahang, Malaysia \\ ${ }^{2}$ Sustainable Energy \& Power Electronics Research Group, Fakulti Kejuruteraan Elektrik \& \\ Elektronik, Universiti Malaysia Pahang, Malaysia
}

\begin{abstract}
Today the electric vehicle (EV) has been developed in such a way that electronic motor, battery, and charger replace the engine, tank and gasoline pump of the conventional gasoline-powered [1]. In other word, instead of using fossil fuel to move the vehicle, in this case we used a pack of batteries to move it. The global climate change and the abnormal rising international crude oil prices call for the development of EV [2]. To solve these problems, a new energy needs to be developed or optimized in order to replace the current energy which is fossil fuel. A clean and green energy [2]. Because of this, it is very important to make sure that the battery that being used is reliable as the fossil fuel. Thus, the design of the battery management system plays an important role on battery life preservation and performance improvement of EV [3]. The BMS also performs many tasks including the measurement of system voltage, current and temperature, the cells' state of charge (SOC), state of health ( $\mathrm{SOH}$ ), remaining useful life (RUL) determination, controlling and monitoring the charge / discharge characteristics and cell balancing [3]. For this project, 18650 Lithium-Ion battery is used to develop battery management for $144 \mathrm{~V} \mathrm{50Ah}$. As lithium-ion batteries have high value of specific energy, high energy density, high open circuit voltage, and low self-discharge, they are a proper candidate for EVs among other cell chemistries [4].
\end{abstract}

\section{Introduction}

The purpose of this paper is to provide a review of past research efforts related to Battery Management System (BMS) for electric vehicle and 18650 Lithium-Ion battery. Some articles discuss on the importance of BMS in electric vehicle while others focusing on the balancing of the State of Charge (SOC) of the battery. The articles discussed on how the BMS help in prolonged the life span of the battery used through cell balancing. The review of the articles showed that the BMS provided the users various operating parameters that

*Corresponding author: mikram@ump.edu.my 
very important to take the EV to next level, reliability enough to replace current vehicle that used fossil fuel to power up the vehicle.

\section{Battery management systems}

The battery need to be protected from high voltage or critical operation conditions. High voltage management need to be developed according to the safety standard of EV such as unbalance cell of the battery [5]. The system also monitors and manages vehicle battery modules, and provides early warning protection [2]. That why BMS are important subsystem for hybrid and electric vehicle, which also ensures that the batteries are operating within the specified conditions [3].

\section{Cell balancing}

Cell balancing is one of the main functions of BMS. A battery is balanced when all of the cells are exactly at the same SOC. The battery may be unbalanced in multiple ways including; SOC, self-discharge current, internal resistance, and capacity. The balancing topologies can be categorized as passive and active balancing [3].

\section{PASSIVE BALANCING}

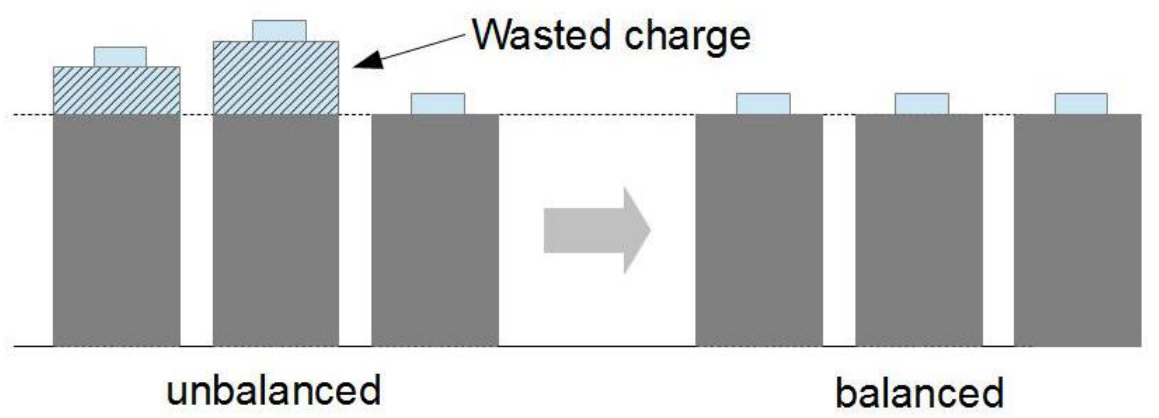

Fig. 1. Passive balancing

Passive cell balancing balance the battery by sampling all cells voltages, levelling all voltages to the lowest among the cells by removing charge from these higher potential cells [3]. 


\section{ACTIVE BALANCING}

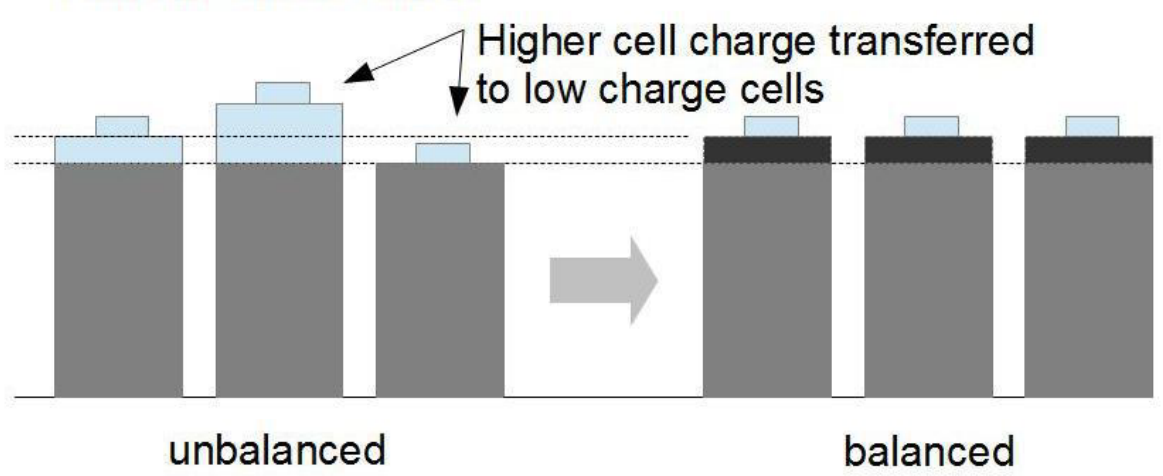

Fig. 2. Active balancing

Active cell also samples all voltages but in different way, by calculating the mean value of the cells then transferring the charge from the cells over this mean value to the cells under the mean value. No waste[3].

\section{Protection}

This system will cut off the relay that measure the voltage between positive and negative terminal of the battery if it detects overcharge, over discharge, overload and short circuit[6]. Place the figure as close as possible after the point where it is first referenced in the text. If there is a large number of figures and tables it might be necessary to place some before their text citation.

\section{Lithium-ion Battery}

This project focuses on the management of secondary Lithium Ion cells because of their energy density compared to other types as shown in the graph below Figure 2. Panasonic NCR18650 Lithium-Ion battery was used for this project. The target voltage for this voltage is $58.8 \mathrm{~V}$ while the target current is $15 \mathrm{maH}$. In order to archive the target values, amount of cell needed are 70.14 series and 5 parallels. The arrangement of the battery is shown in Figure 6. 
- High Voltage

Ni-Cd. Three series of $\mathrm{Ni}-\mathrm{Cd} / \mathrm{Ni}-\mathrm{MH}$
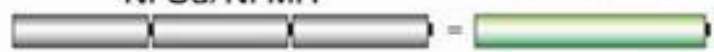

- High Energy Density

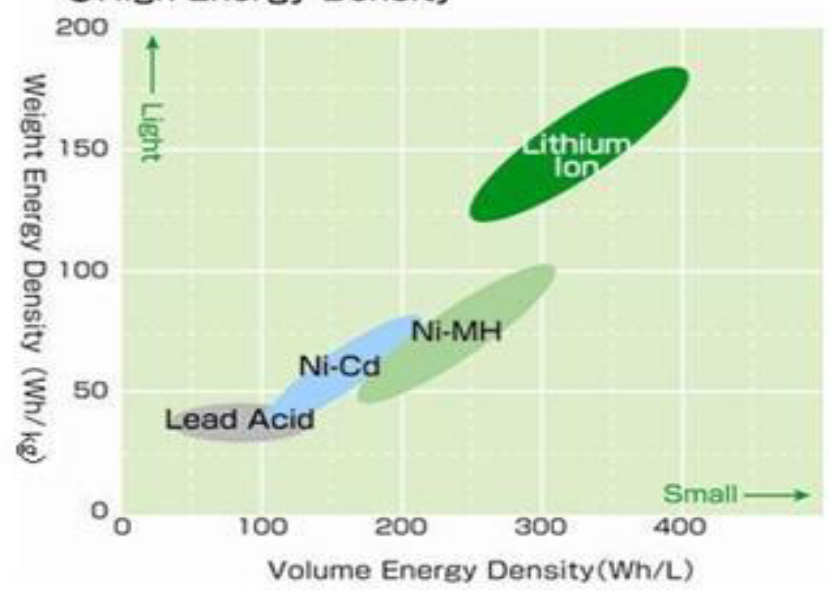

Fig. 3. Comparison of various battery types

This type of battery also has more density, long life cycle and more safety for many applications [7]. This battery also more cheap compare to other rechargeable battery.

Table 1. Specifications of battery

\begin{tabular}{|c|c|}
\hline Rated capacity & Min. $2700 \mathrm{mAh}$ \\
\hline Capacity & $\begin{array}{l}\text { Min. } 2750 \mathrm{mAh} \\
\text { Typ. } 2900 \mathrm{mAh}\end{array}$ \\
\hline Nominal voltage & $3.6 \mathrm{~V}$ \\
\hline Charging & $\begin{array}{c}\text { CC-CV, Std. } 1925 \mathrm{~mA}, 4.20 \mathrm{~V}, 3.0 \\
\text { hrs }\end{array}$ \\
\hline Weight (max.) & $46.5 \mathrm{~g}$ \\
\hline Temperature & $\begin{array}{c}\text { Charge: } 0 \text { to }+45^{\circ} \mathrm{C} \\
\text { Discharge: }-20 \text { to }+60^{\circ} \mathrm{C}\end{array}$ \\
\hline Energy density & $\begin{array}{l}\text { Volumetric: } 577 \mathrm{Wh} / 1 \\
\text { Gravimetric: } 214 \mathrm{Wh} / \mathrm{kg}\end{array}$ \\
\hline
\end{tabular}




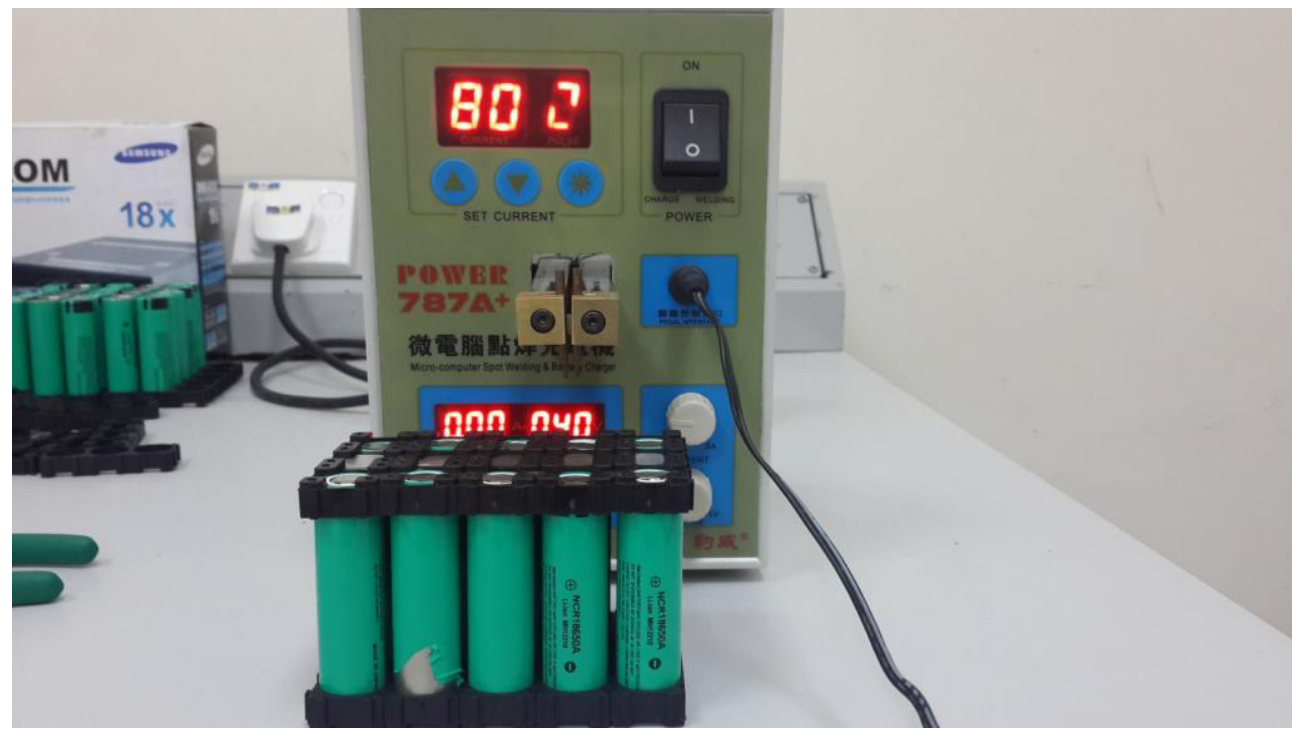

Fig. 4. Spot weld battery in progress

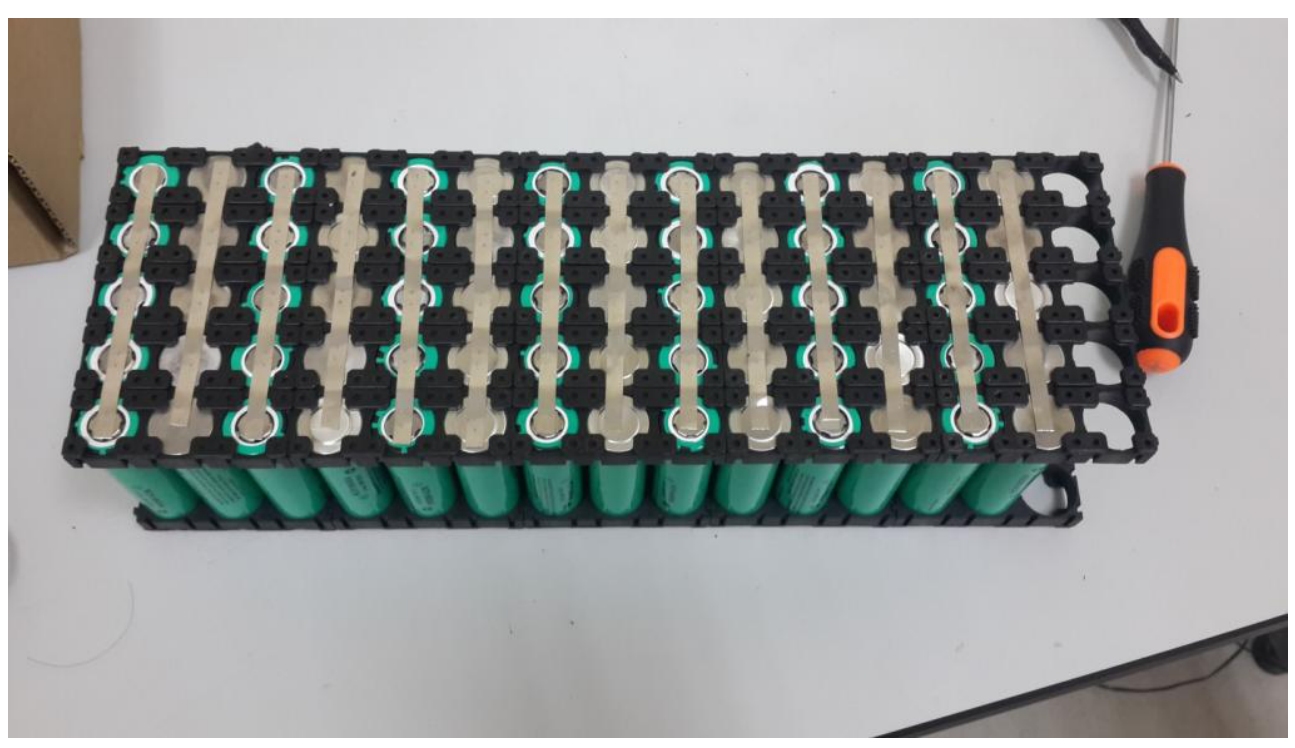

Fig. 5. After spot weld completed 


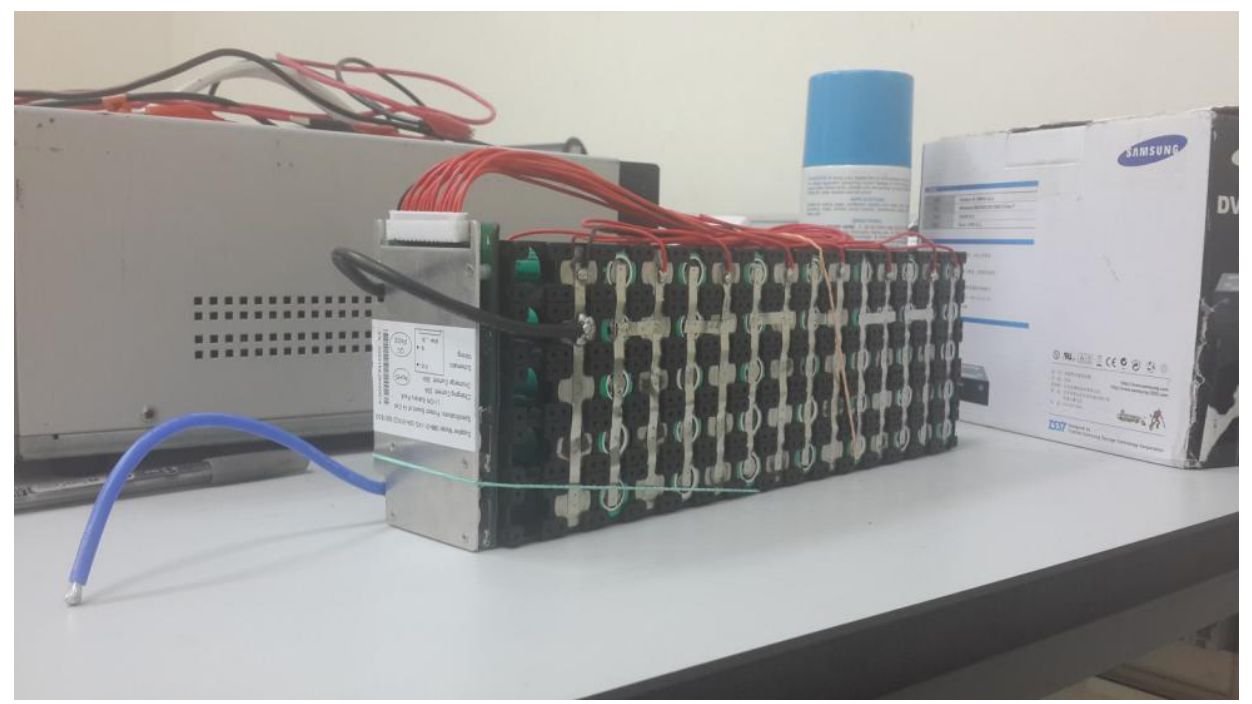

Fig. 6. Battery with battery management system

\section{Simulation results}

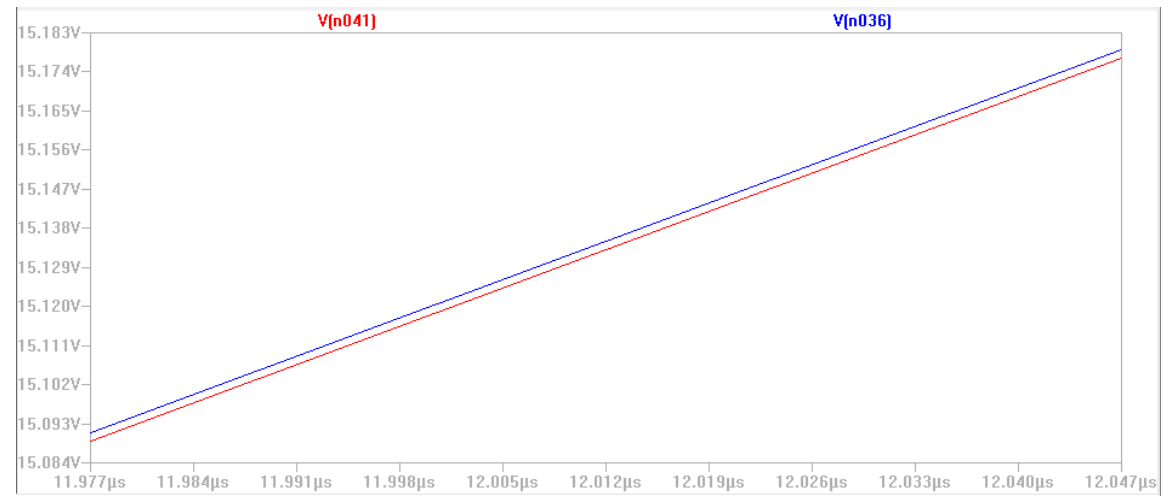

Fig. 7. LTSpice Simulation Charging of cells

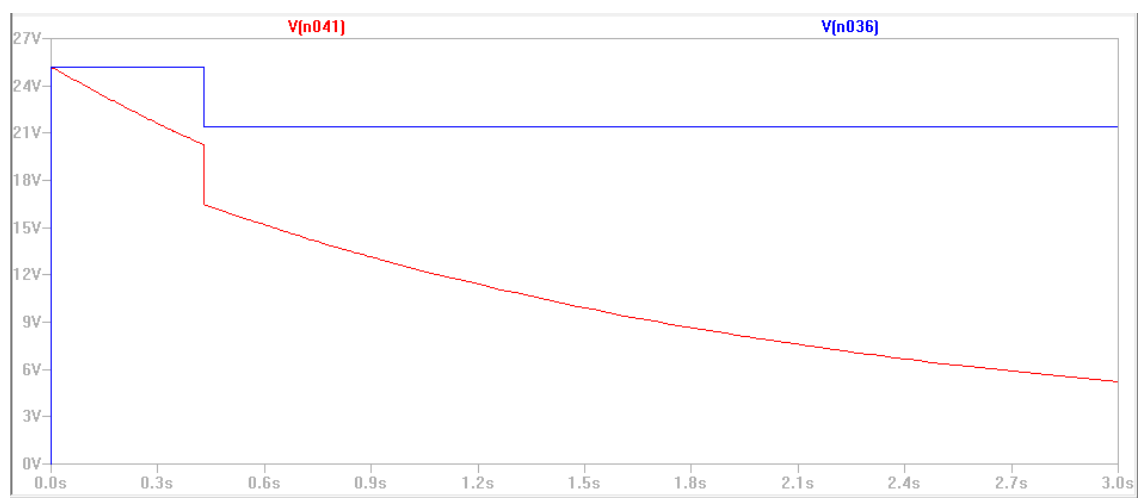

Fig. 8. LTSpice Simulation 
The graph obtained from the simulation shows the charging and discharging of the battery. From Figure 8, the graph keeps increasing with time until it reached 25.2 V. The voltage for each cell used in this simulation is $4.2 \mathrm{~V}$. So total voltage for 6 cells are $25.2 \mathrm{~V}$. Once the voltage for all 6 cells reached it optimum voltage, the cells will stop charging. Red line in the graph represents the charging and discharging of the battery pack. While the Blue line represents the total voltage for 6 cells. The graph shown in Figure 9 and Figure 10 is only for one IC. In order to achieve the total voltage needed for this project, three IC were needed. After the battery is fully charged, it will start to discharge. From the simulation, one of the main functions of BMS can is proven, protection from overcharged.

\section{Summary}

After implementation of battery management system, the lifespan of the battery is much longer than the one without it and to ensure the battery operating within safe operating system.

This project was financially supported by Universiti Malaysia Pahang with RDU 150340.

\section{References}

1. C.L. Wey, P.C. Jui, International Conference on Connected Vehicles and Expo (ICCVE), 903 (2013)

2. C.H. Lin, H.Y. Chao, C.M. Wang, M.H. Hung, International Conference Proceedings/TENCON, 863 (2011)

3. M. Bowkett, K. Thanapalan, T. Stockley, M. Hathway, J. Williams, $19^{\text {th }}$ International Conference on Automation and Computing (ICAC), 1 (2013)

4. P. Amiribavandpour, W. Shen, A. Kapoor, IEEE Vehicle Power and Propulsion Conference (VPPC), 117 (2013)

5. J. Qiang, L. Yang, G. Ao, H. Zhong, International Conference on Vehicular Electronics and Safety (ICVES), 134 (2006)

6. N. Haq, E. Leksono, M. Iqbal, F.X.N. Soelami, D. Kurniadi, Int. Conf. Electr. Eng. Comput. Sci., 203 (2014)

7. K.J. Chung, C.C. Hsiao, International Conference on Computer, Consumer and Control (IS3C), 2(3), 930 (2012) 